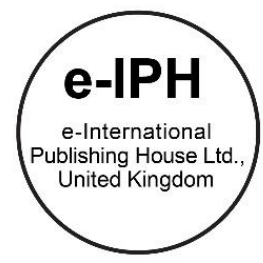

\title{
Unique Land Use Pattern and Travel Behavior on Waterborne Transport
}

\author{
Sauvanithi Yupho ${ }^{1 *}$, Tienwanan Jomsueb 2 , Panit Pujinda 3 \\ 1 Healthy Space Forum, G.P.House 71, Sap Rd, Sri Phraya, Bangrak, Bangkok 10500, Thailand \\ 2,3 Department of Urnan and Regional Planning,Faculty of Architecture,Chulalongkorn University, 254 Phayathai Rd, Pathum Wan, Bangkok 10330, Thailand
}

\begin{abstract}
Before the emergence of paved road and highways, waterways and waterborne transport once were the heart of transportation that provided mobility and flexibility for Thais. Cities relied on waterways for commerce, socio-economic opportunity, and leisure until the advent of motorway development. Many canals were covered over and turned into streets, while cities were converted to inland development, resulting in the decline of the role of waterways. However, at present, there are four waterways that are making a comeback due to the ever-congested traffic on roads. Currently, water transit accounts for only three percent of transport modes (Trip Generation Model, 2011), but the key waterways provide direct and efficient travel to central Bangkok. Although it is an escape from inland-traffic, waterborne transport itself has various limitations on catchment area that requires different travel behavior.
\end{abstract}

Keywords: Waterborne Transport; Travel Behavior; Land Use Pattern; Bangkok

ISSN: 2398-4287@ 2017. The Authors. Published for AMER ABRA by e-International Publishing House, Ltd., UK. This is an open access article under the CC BYNC-ND license (http://creativecommons.org/licenses/by-nc-nd/4.0/). Peer-review under responsibility of AMER (Association of Malaysian Environment-Behaviour Researchers), ABRA (Association of Behavioural Researchers on Asians) and cE-Bs (Centre for Environment-Behaviour Studies), Faculty of Architecture, Planning \& Surveying, Universiti Teknologi MARA, Malaysia.

\subsection{Introduction}

Waterborne transportation in and around Bangkok was thriving long before the city was founded. The rivers and canals were vital arteries for commerce, transport, and recreation. However, roads and highways steadily eroded use of the river and canals since motor vehicle transport was seen as more modern. However, in recent decades, vehicle traffic in Bangkok has become so congested that time of daily commute is one of the highest in the world and average speed during rush hour is $15 \mathrm{~km} / \mathrm{hr}$ (Transport and Public Policy Plan Office, 2015) while to average walking speed of $6 \mathrm{~km} / \mathrm{h}$. Thus, there is more pressure on urban planners to make better use of the remaining waterways in and around Bangkok. The four principal waterways run north-south and east-west, connecting residential areas with 'old town' and the central business district (CBD). Waterway transit has generally been ignored by traffic planners, with the focus more on elevated highways, elevated mass rail transit, and subway. However, it is becoming harder to ignore the potential and efficiency for greater use of Bangkok water links. The Chao Phraya River commuter boats transport about 13 million person-trips per year. This is largely possible through the efficient operation of the Chao Phraya Express boat system, and cross-river ferries. The river itself has 39 piers within the Bangkok city limits and five service routes (Fig.1)

This study aimed to understand land use patterns around each Chao Phraya River pier according to the five service routes together with travel behavior of boat riders. The travel behavior of boat riders has different pattern and user according to the limitation of boat catchment areas and service timing. Use pattern is classified as a concentric ring, sectorial plan and multi-nuclei (Fig. 2). This study found that land use patterns around the piers fall into the concentric ring and multi-nuclei patterns. The area around some of the piers nearer the CBD had a very high concentration of economic activity since they are crossroads to and from work/school/shopping destinations. The piers that accommodate three service routes had a multi-nuclei land use pattern with moderate economic activity around the piers but that activity grows and expands as one travels away from the pier. By contrast, the land use pattern around the piers that serve 1 - 2 service routes are a concentric ring pattern with less economic activity around the piers since those serve more as feeder routes to other forms of mass transit.

\footnotetext{
* Corresponding author. Tel.: +66 (0) 819216608

E-mail address: svnithi.y@gmail.com
}

ISSN: 2398-42870 2017. The Authors. Published for AMER ABRA by e-International Publishing House, Ltd., UK. This is an open access article under the CC BYNC-ND license (http://creativecommons.org/licenses/by-nc-nd/4.0/). Peer-review under responsibility of AMER (Association of Malaysian Environment-Behaviour Researchers), ABRA (Association of Behavioural Researchers on Asians) and CE-Bs (Centre for Environment-Behaviour Studies), Faculty of Architecture, Planning \& Surveying, Universiti Teknologi MARA, Malaysia.

DOI: http://dx.doi.org/10.21834/e-bpj.v2i5.707 


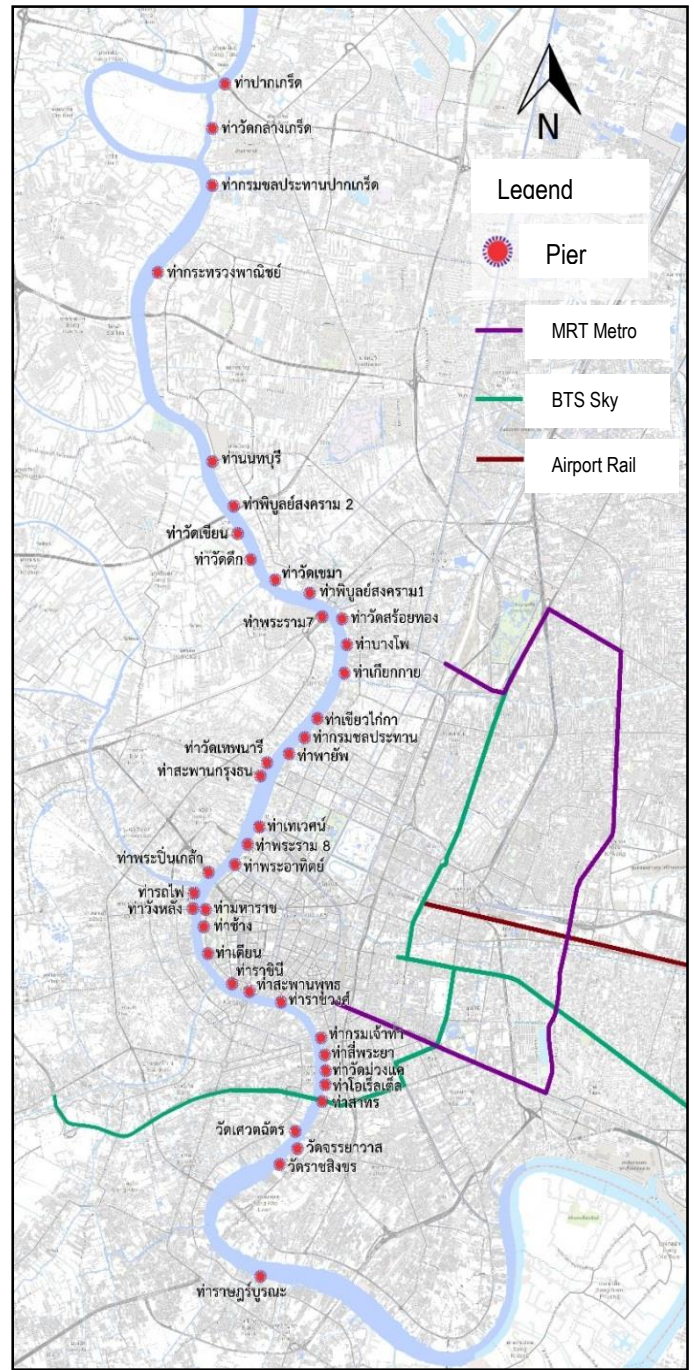

Fig. 1: Chao Phraya Express boat system - 39 Piers (Source: authors)

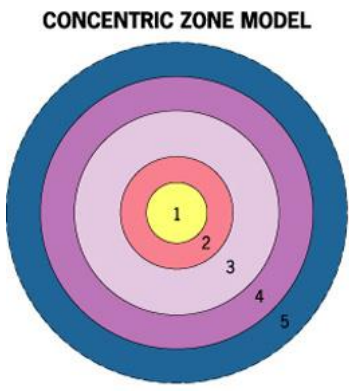

A

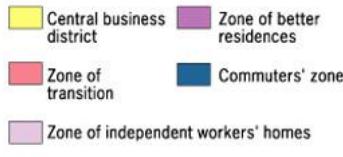

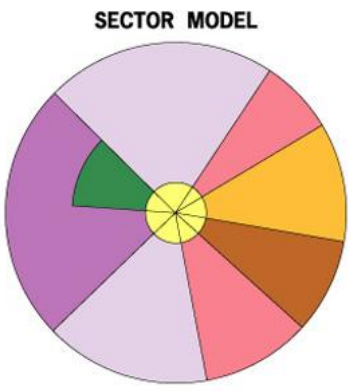

B

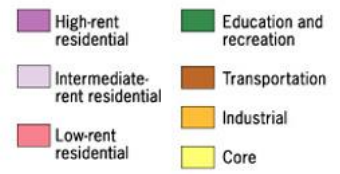

MULTIPLE NUCLEI MODEL

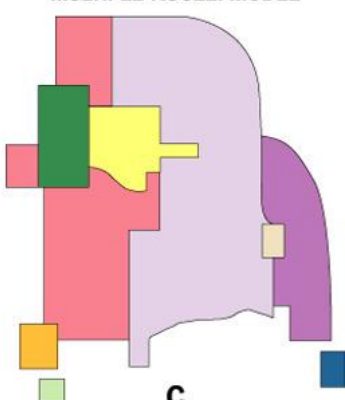

C

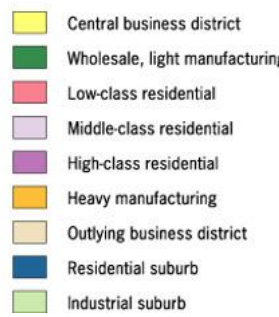

$\square$ Industrial suburb

Fig. 2: concentric zone model, sector model and multiple nuclei model (Source: http://arjungeography.blogspot.com/2014/01/concentric-zone-model-1-central.html) 


\subsection{Literature Review}

Thailand has a strong history of use of canals and rivers as important means of transport and travel. As recently as 2005, Thailand had mail delivery boats which plied the canals which connect rivers with residential areas. However, things began to change in 1961 when Thailand introduced the 1st Five-year Economic and Social Development Plan. That, and subsequent plans, gave increasing importance to the road network and land transport to accommodate the rapidly expanding Thai economy. The potential for the waterways to be an integral part of this expansion was largely ignored by the development planners. During the 5th Plan period, the cost of oil spiked and forced the government to institute measures to economize fuel for transit. This renewed interest in the waterways as an alternative delivery mechanism, especially in and around Bangkok.

\subsection{Importance of boats and ferries for commuter transit in the urban setting}

Historically, the rivers and canals were a significant means of transporting goods, services, and people, both domestic and international. Today, these waterways are diminished in importance because of the accelerated construction of elevated roads and mass rail transit. Travel by river/canal or ferry is usually more economical and cooler than traveling by non-air-conditioned bus or car, as long as one's origin and destination are near a pier. Thus, there has been a gradual expansion of piers and commuter vessels to provide an alternative. In addition, visionaries are helping to transform the areas and buildings around the piers as important shopping, cultural and commercial destinations in addition to functioning as a conduit to elsewhere.

In central Thailand, river and canal transit emerged as an important mode of travel because the historical capital cities of the country (Sukothai, Ayutthaya) were located in predominate flatland and river basins. Indeed, boat travel was probably a necessity for many communities and at different times of the year. Water transport continued to be important even as the capital of the country moved south. In 1860 (Rattanakosin Era) water transit was formalized as a part of Thai law. Historically, river transit was dominated by commerce, large and small. It wasn't until around 1942 when commuter boats were introduced, and these have expanded steadily, but slowly, to the present. The major boat commuter routes for Bangkok travel along the Chao Phraya River, the Saen Sap Canal, the Phrakanong Canal, the Ban Pa Canal, and Pasi Jaroen Canal. For commuters who live/work/attend school near the piers, these water transit services are invaluable. In addition, tourists are heavy users of the Chao Phraya Express boat services, especially during non-peak hours. The expansion of the population in the suburbs, and the worsening road traffic congestion means that commuters by car or bus have to travel farther and longer each year. Thus, the perceived value of water transit is bound to increase steadily in the coming years, and is not close to achieving its true potential.

This study focuses on the section of the Chao Phraya River which bisects Bangkok into east and west. The river has important economic, residential and cultural features on both sides, and most piers are in reasonable walking distance to a bus stop, mass rail transit or feeder transit (e.g., taxis, motorcycle taxis, Tuk Tuks and shuttle pick-ups). In 2015, the Department of Harbors (DOH) reported over 13 million person-trips to/from piers along the Chao Phraya River. In addition to being a vital commuter route in its own right, there are numerous cultural, religious and historical attractions along the river which attract Thais and foreign tourists alike. At night, river dinner cruises flow back and forth down the river providing a unique experience and ambiance.

\subsection{Modes of water transit}

For commuters in and around Bangkok, the Chao Phraya River is the principal mode of water transit. The river connects the capitals of suburban provinces (Nonthaburi and Pathum Thani) with the CBD. Canals spear off from the river to reach neighborhoods and markets in the interior. Because of the different widths and depths of the river and canals, the boats are modified to provide an optimal balance of safety and commuter capacity. The Chao Phraya Express river boat service has different size vessels which can accommodate from 60 - 150 passengers, both seated and standing. By contrast, the boats that ply Saen Sap Canal are narrower and have maximum seating for 48 persons. Clearly, there is room for increased commuter capacity along the Chao Phraya River and canals, but the lack of adequate government support for infrastructure is impeding expansion. For example:

- Some piers are old and in need of repair. In other sites, piers may flood during high tide in the late part of the rainy season.

- The piers are public property and, thus, some non-commuters encroach on these public spaces, making it difficult for others to pass by.

- There is an inadequate budget for repair and restoration of the piers.

- There is no permanent, full-time agency that oversees the piers. The DOH merely facilitates access for the public to the boats; there is a need for closer oversight and management of the piers. The roads and other facilities adjacent to the piers are under the authority of a variety of entities (e.g., local administrative organizations, Highways Department, and private owners, among others. Thus, there is the lack of coordination for development.

- Even though most of the piers are within walking distance to land transit options, in many cases the walkways from the pier are too narrow or lack adequate lighting.

- As more and more people turn to water transit, it is becoming hard to control the number of passengers at rush hour, possibly exceeding safe capacity.

- For safety reasons, the commuter boats generally run only from dawn to dusk, thus eliminating water transit for important parts of the workday and weekend.

In sum, even though river transit is convenient, fast, and inexpensive, the transit systems are not achieving their full potential because of infrastructure, budget, and management issues. 


\subsection{Special features of water transit}

A study by Suramet Pitiyarwat presented the following unique attributes of water transit in the larger context of mass transit and commuting in the city:

\section{Motor vehicle or car}

Travel in the city can be by a single mode of transit, mixed-mode, and linked services. Trains and buses have rather standard and fixed capacities and, thus, unless they are operating at full capacity, then there are inefficiencies in the system (e.g., large buses which are largely empty riding around Bangkok during non-peak hours). By contrast, different modes of river transit can be employed at different times of the day that are tailored to demand. For example, there are ferries operating at different frequencies, and different sizes of commuter boats for peak and non-peak hours. Long-tail boats are available to fill gaps in demand and supply along the river and canals.

\section{Ways, transit ways, right-of-way}

Roadways have fixed lanes for cars and, in some cases, bus lanes or BRT. There are also fixed tracks for heavy rail and mass rail transit. By contrast, the larger waterways such as the Chao Phraya River have more flexibility of movement and can make adjustments to more efficiently use the waterway area. Commuter vessels share the river with large barges, hauling sand or rice, as well as with the smaller faster vessels such as the long-tail boats, and share piers with the cross-river ferries. Thus, only rarely does one see traffic jams on the river.

\section{Transit stop facilities}

Road and rail mass transit have a system of stops, stations, and terminals. Bangkok mass transit is characterized by multi-modal transfer stations in which commuters can shift from one form of transit to another, minimizing delays and maximizing efficiency. The river piers are a nexus of multi-modal transfer and, the more favorable environmental conditions along the river (less pollution, noise, congestion), make the piers an enjoyable place to relax while waiting for the next boat or ferry. Most piers have ample seating.

\section{Relevant systems}

Land/rail Transit Control systems: This refers to tracking, communications, and signaling equipment to help with traffic management, including the power supply systems for mass rail. By contrast, river and canal transit has no electric systems or signals or outboard power supply. Instead, this requires that the boat operators comply with a set of conventions on passing, right-of-way, use of whistles, and hand signals. Deployment of boats needs to be more carefully controlled at each terminus to avoid crowding of the waterways and back-ups at the piers.

Because of the increasingly important role of water transit in/around Bangkok, the piers are being seen as more than just a transit stop. Instead, more and more piers and surrounding neighborhoods are being developed into attractive destinations in their own right, with shopping, relaxation, cultural attractions and entertainment being integrated into the pier-community nexus.

\subsection{Concepts of transit and optimal use of the surrounding land}

A review of the literature shows that more cities are focusing on the interface between transit routes and the immediate neighborhoods they intersect with in order to enhance the commuter experience and stimulate the micro-economy and culture around piers. The goal is an optimum movement of people, goods and services between locations for maximum socio-economic benefit. In this concept, development of the transit experience and transfer locations can be mutually reinforcing. This involves a more comprehensive vision of public amenities and private services, and more creative use of high-density environments. The city center usually has a variety of transit options including pedestrian, bicycle, mass transit, etc., to link origin and destination (Ashir Lanree, n.p.). Yet there needs to be a greater emphasis on appropriate land use tailored to the transit nexus.

The theory and concepts on mass transit and land utilization point toward the synergy between travel and transit in areas of less than 10,000-persons density. That level of human movement and interaction is also an appropriate size for developing water transit where feasible. The pier and surrounding areas need to be designed or reconstructed to accommodate this level of human traffic. However, in the context of Bangkok, with myriad agencies and interests involved in waterfront development, it is hard to implement a unified vision of accessible amenities. As a result, development tends to expand away from the waterfront rather than along it. As a preliminary step for addressing this problem, the author has attempted to clarify the relationship between the pier and land use around the pier. The study looks at commuter behavior and activities of vendors and outlets surrounding the pier area. Based on the findings, the author proposes strategies to optimize use of the pier and vicinity to meet the needs of commuters, public amenities and vendors.

\subsection{Waterborne Transport in Hong Kong}

Star Ferry is a passenger ferry connects between cities along Victoria Harbor. The similarity of Hong Kong Ferry and Chao Phraya Ferry is that it serves through historical route and connects between historical, touristic, and central business areas. It has been operated more than a century between Hong Kong Harbor and Tsim Sha Tsui. This ferry has become Hong Kong cultural icon because it has been transportation hubs that provide high connectivity among the harbor. It also helps increasing development potential around the service areas. Although the role of the Ferry has changed from trading purpose to passenger service, the history, 
cultural characteristics and architecture style remain. Nowadays, the Star Ferry serve between Tsim Sha Tsui and Wanchai, Tsim Sha Tsui and Central within 5-10 minutes.

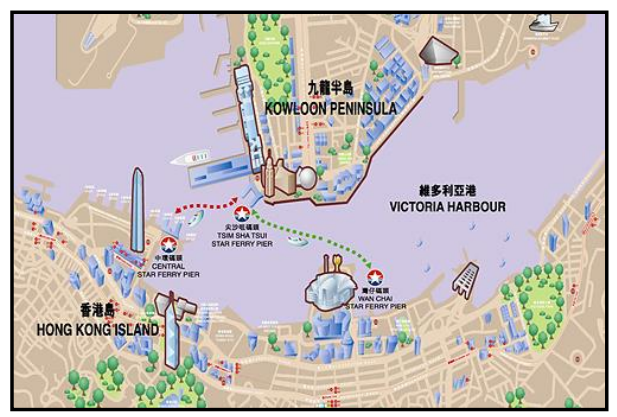

Fig.3 Star Ferry Route

(Source: http://www.starferry.com.hk/en/service)

\subsection{Methodology}

Steps and methods

3.1 Study and explain the role of the modes of travel by waterways in relation to the larger commuter context: Table 1 presents details.

\begin{tabular}{ll}
\multicolumn{1}{c}{ Modes of transit } & Table1. Details of the Study of Waterway Transit \\
\hline Physical outlay & $\begin{array}{l}\text { Study of the natural characteristics of the course of the Chao Phraya River, impacts on the waterfront, the terrain, } \\
\text { earth layers and breaches of the bank that have implication for development of the waterfront. } \\
\text { Study of the patterns of waterway transit and importance of water transport, with examination of historical } \\
\text { development of water transit in the city and inefficiencies }\end{array}$ \\
$\begin{array}{l}\text { Network of water transit and links with other } \\
\text { transport }\end{array}$ & $\begin{array}{l}\text { Compile data on the network of water transit and links with on-going forms of travel, which in turn impact on } \\
\text { demand for water transit. }\end{array}$ \\
\hline
\end{tabular}

\subsection{Analysis of the importance of commuter boat piers to select study sites.}

(1) Grouping piers by importance of attributes, superimposed by features of the piers (Tables 2)

Table2. Factors Affecting Selection of Study Sites

\begin{tabular}{|c|c|}
\hline Factors & Steps in the Analysis \\
\hline Type of vessel route & $\begin{array}{l}\text { Arrange all the commuter boat piers into the following six groups: } \\
\text { - } \quad \text { Piers with five modes of water transport and links with mass rail transit (e.g., Sathorn); } \\
\text { - } \quad \text { Piers with five modes of water transport (Wang Lang, Ratchawong and Si Phraya) } \\
\text { - } \quad \text { Piers with four modes of water transport (Nonthaburi, Rama VII, Thevet, and Phrapinklao) } \\
\text { - } \quad \text { Piers with three modes of water transport (Thonburi Bridge, Chang, Phra Athit, and Oriental) } \\
\text { - Piers with two modes of water transport (Kiak Kai, Payap, Memorial Bridge, DOH, Wat Worajanyawat, and } \\
\text { - Wat Ratchsingkorn) } \\
\text { Piers with one mode of water transport (Pak Kret, Wat Klang Kret, Ministry of Commerce, Rama V, Pibul } \\
\text { Songkram 2, Wat Khian, Wat Teuk, Wat Kamao, Pibul Songkram 2, Wat Soi Thong, Khiao Kai Ka, Dept. of } \\
\text { Irrigation, Wat Thepakorn, Wat Thepnari, Rama VIII Bridge, Rot Fai, Ratchini, Muang Kae, Wat Sawatechat, } \\
\text { Maharat, Wat Ratburana }\end{array}$ \\
\hline Density of pier utilization & $\begin{array}{l}\text { Each of the piers is superimposed on a map of commuter density (high, medium and low) to assess commuter } \\
\text { traffic }\end{array}$ \\
\hline Location of the pier & $\begin{array}{l}\text { Superimpose the piers with a graphic with data on utilization of the pier as follows: Single use, double use, triple or } \\
\text { higher use to assess density by type of use }\end{array}$ \\
\hline $\begin{array}{l}\text { Links with other modes of transit (public mass } \\
\text { transit, vans, shuttle pick-ups) }\end{array}$ & $\begin{array}{l}\text { Superimpose the piers with a graphic with data on transfer options as follows: Piers with one, two or three transfer } \\
\text { options. }\end{array}$ \\
\hline Type of commuter pier & Superimpose piers by type of location: hub, origin, terminus, ferry \\
\hline Size of piers & Superimpose piers with graphic on large, medium and small piers with different commuter capacities \\
\hline
\end{tabular}

(2) Consider initial components and select two piers per group, stratified by an ability to provide services (except for the pier with five modes of water transit and link to mass rail transit (i.e., Sathorn).

(3) The following are the 11 study sites by group (Fig.3):

Group 5 Service Routes and connected to mass rail transit: Sathorn 
Group 5 Service Routes: Wang Lang, Si Phraya

Group 4 Service Routes: Nonthaburi, Rama VII

Group 3 Service Routes: Tien, Oriental

Group 2 Service Routes: Payap, Wat Ratchsingkorn

Group 1 Service Route: Pak Kret, Wat Ratburana

\subsection{Analysis of changes in the area around the commuter piers}

This involved analysis of aerial photographs of the pier area along the Chao Phraya River over a 20-year period (1996-2016) and interpreting changes in terms of land utilization in the area radiating out from the piers for a distance of 400 meters.

\subsection{Survey patterns of land utilization in the study sites: with a focus on the following factors}

Type of use of land and structures, using GIS mapping and on-site survey within a 400-meter radius;

Density of land use, as calculated from the area in a 400-meter radius from the pier;

Road infrastructure and access lanes

Document obstacles to access to assess safety and convenience of accessing the pier, both for walkways, and traffic routes

\subsection{Survey of utilization behavior of a sample of 421 pier commuters, with the following items:}

Socio-economic characteristics of the commuters and radius of pier services;

Mode of travel, to reflect efficiency to transit from the pier to destination;

Destination, to reflect utilization of amenities, outlets in/around the pier, for both arrivals and departures, and by a time of day.

3.6 Analysis of the relationship between the importance of the commuter piers and land use, across the following dimensions:

Describe linkages between the pier land utilization along the way to compare mode, network, and pattern of urban expansion;

Describe how commuter behavior interacts with land utilization to reflect the relationship of the destination with surrounding land utilization, by a time of transit to/through the pier area.

3.7 Recommended guidelines for land utilization in the area of commuter piers in ways that are consistent with future development.

\section{Analysis tools:}

\subsection{Survey of the physical layout}

Data analysis relied on geographic assessment, especially in terms of utilization of land, buildings, and structures, the density of the activities. One purpose of that analysis was to determine the variation of land utilization, density of traffic and importance of a given pier. Other factors include surrounding road network, laws and regulations, general characteristics of the lay-out and obstacles (see Table 3).

\begin{tabular}{ll}
\multicolumn{1}{c}{ Variable } & Table 3: Accessibility Indicators \\
\hline Lack of continuous pedestrian paths & \multicolumn{1}{c}{ Explanation } \\
Safety from crime & There is an interruption of pedestrian space with other objects and uses which \\
impede movement & Sense of safety along entire route \\
Conveniences & Readiness of public amenities for pedestrians for increasing convenience and \\
Amenities for the disabled & comfort \\
Maintenance and hygiene & Ability of the infrastructure to accommodate the disabled \\
Obstructions & General condition of the locality \\
& Temporary and permanent obstacles in the pedestrian pathways impact on \\
& flow of pedestrian traffic \\
\hline
\end{tabular}

\subsection{Questionnaire survey}

The questionnaire content was divided into three sections as follows:

Socio-economic and other background information;

Modes of travel and travel behavior of the commuters

Destination, and features of the pier area which the commuter utilizes

\subsection{Population of interest and sample population}

There is a varied use of the land and structures around the piers in this study. Commuters also have different purposes for transit through the pier. The data from the DOH show the number of boat commuter visits in each of the piers along the Chao Phraya River. The author used simple random sampling with equal probability of being selected. The formula cited in Bunchu Srisa-at (1992) was used to determine sample size as follows: 


$$
N=\frac{P(1-P)}{\frac{e^{2}}{Z^{2}}+\frac{p(1-p)}{N}}
$$

where $\quad n=$ number of the sample

$\mathrm{N}=$ total population

$\mathrm{P}=$ proportion of the population designated for inclusion

$\mathrm{e}=$ acceptable level of variance

$Z=$ level of confidence $(Z=2.58)$ at $p<0.05$

If the number of commuter visits at the 11 selected piers is 252,599 then

$$
\begin{aligned}
252,599= & \frac{0.20(1-0.20)}{\frac{(0.05) 2}{(2.58) 2}+\frac{100(1-0.20)}{252,599}} \\
& =425.61
\end{aligned}
$$

The sample was rounded down to 400 to conserve time and costs.

\subsection{Distribution of the questionnaires}

Because of the different volume of commuters in the various sites, the author had to do an extrapolation as referenced in Niyom Purakam (2014), as follows:

$$
n h=\frac{\mathrm{Nh}}{\mathrm{N}} \times n
$$

Where $\quad \mathrm{nh}=$ number of selected piers

$n=$ total sample desired (i.e., 400)

$\mathrm{Nh}=$ number of commuters passing through the piers

$\mathrm{N}=$ number of commuter trips through the piers: 252,599

Table 4: Number of questionnaires filled out by pier and time of day

\begin{tabular}{lcccc}
\hline \multicolumn{1}{c}{ Piers } & Morning rush hour & Evening rush hour & Off-peak & Total \\
\hline Sathorn & 13 & 14 & 76 & 103 \\
Wang Lang & 10 & 7 & 52 & 69 \\
Si Phraya & 3 & 4 & 19 & 26 \\
Nonthaburi & 19 & 12 & 67 & 98 \\
Rama VII & 7 & 3 & 20 & 30 \\
Tien & 1 & 3 & 26 & 30 \\
Oriental & 1 & 1 & 12 & 14 \\
Payap & 5 & 3 & 15 & 23 \\
Wat Ratchsaingkorn & 2 & 1 & 13 & 15 \\
Pak Kret & 2 & 1 & 5 & 8 \\
Ratburana & 3 & 1 & 1 & 1 \\
\hline & \multicolumn{3}{c}{ Total } \\
\hline
\end{tabular}

\subsection{Analysis of questionnaire data}

Data were analyzed using SPSS to produce cross-tabulations for bi-variate tests of association (Chi-square) between mode of travel and characteristics of the destination, strengths of associations, tendencies and trends, and for development of explanatory models of optimal land use in commuter piers.

\subsection{Findings and Discussion}

The importance of the given piers and land/building utilization in the adjacent areas are not associated at the statistical level of significance. The densely trafficked piers which had been in use for over a century do not show a significant difference during the last 20 years of comparative aerial photography. Today, activity in the most densely trafficked pier (Sathorn) is attributed to the expansion of the on-land transport development (Fig.4). Furthermore, the importance of the given piers, the density of pier activity, and ability to attract commuters from other parts of the city is due to the linkages among the other land transport systems rather than being a terminus or starting point of a line. Thus, the concentration of commuters at the Chao Phraya River piers occurs during the morning and evening rush hours, with the primary goal of the traveler to shorten the commute, rather than enjoy the attractions of the pier neighborhood. 


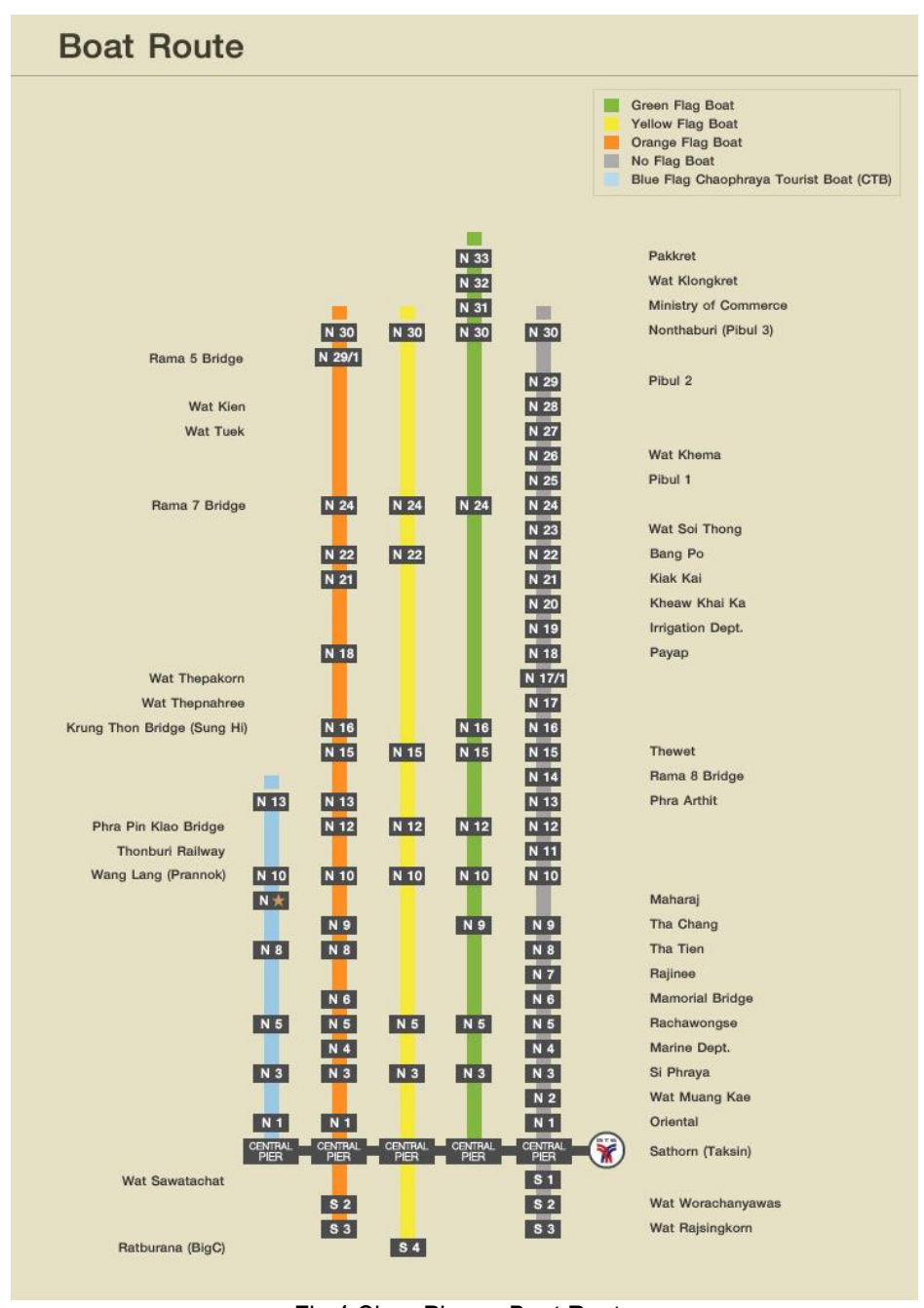

Fig.4 Chao Phraya Boat Route

(Source: http://www.thaibis.com/bangkok/transport/river/station-maps)

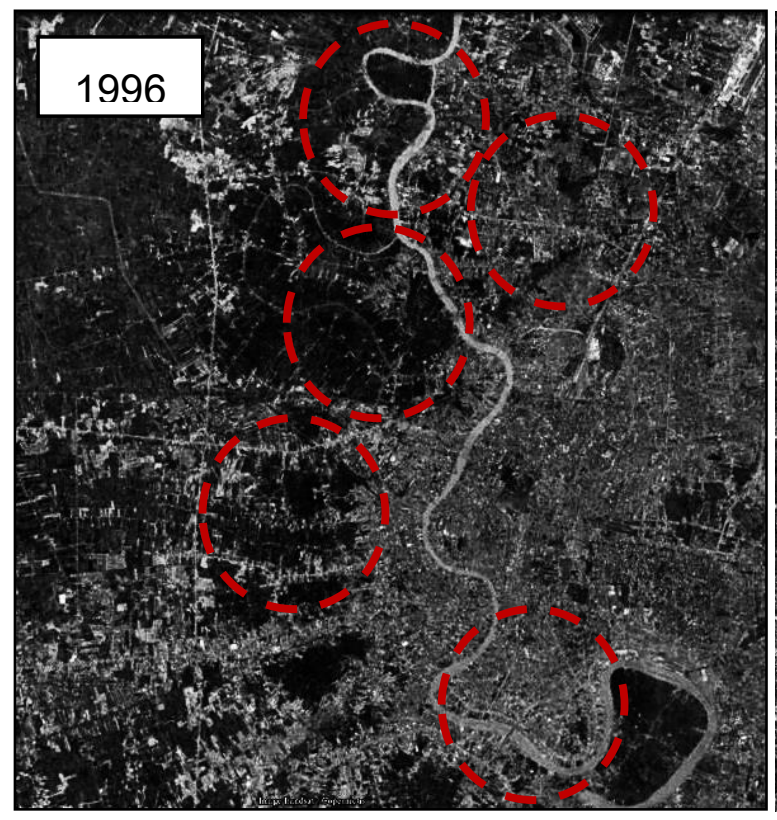

(a)

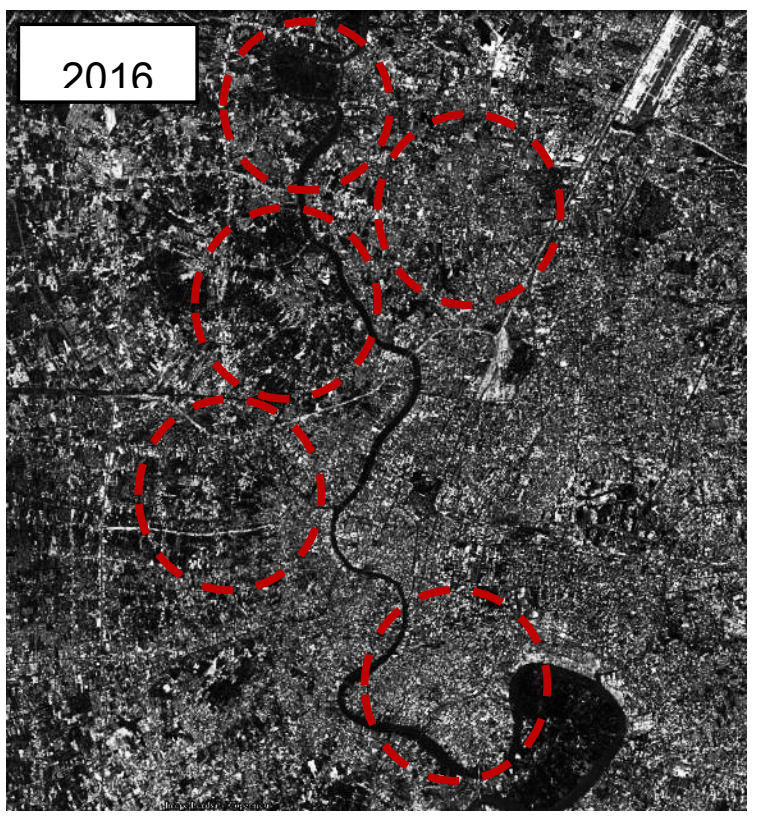

(b)

Fig.5 A comparison of Land Use between (a) 1996 and (b) 2016 
Piers along the Chao Phraya River mainly function as transit hubs due to the straight connectivity to the heart of Bangkok and to avoid peak hour traffic congestion. However, most piers do not have variable abilities to attract travelers to pursue activities around the pier area for their own sake (i.e., not just transit). This is evidenced by the fact that the more popular attractions in the general vicinity of the piers are far beyond a 400-meter walking distance radius extending away from the pier; not adjacent to the piers. This is due to limitations on land utilization along the river, the degraded stability of the river bank (in order to build more or higher), subsidence, and risk of flooding. Moreover, waterborne is principally served the low-income user. Developing adjacent area to the piers/or by the river would create high cost and increase massive economic value in return because of the riverfront location and leisure atmosphere. The services for low-income will be priced out and unaffordable. Nevertheless, it is impossible to ignore the socio-economic potential of these areas which have an enormous promise, while helping to reduce road traffic congestion (Fig.5).

The areas around most of the piers are not residential and, thus, commuters only spend a cursory amount of time in the pier area, en route to other legs of their commute. This partly explains why more of the economic attractions are located beyond the 400-meter radius beyond the pier and along major roads (Fig.6).

The sex of commuters in this sample was $70 \%$ women, and boat transit is the preferred mode of transport for the lower-middle income: One-third of the boat commuters made less than 5,000 baht per month, and this could reflect the lower income of women relative to men, which steers them toward the most economical forms of transit. Unfortunately, only a limited proportion of the lowermiddle and lower income persons in Bangkok have easy access to river transit.

Statistic shown morning services served $10 \%$ commuters more than evening services. Because, as noted, the Chao Phraya River Express boat service stops at about 7-8 p.m. due to the low waterborne security service, it is possible that more commuters use boats to go to work in the morning, but return by other means at night if they cannot board the final boat in time. Thus, commutes through the piers are not necessarily symmetrical (i.e., daily round trips).

Over three-fourths of river commuters at their point of embarkation/disembarkation came from their home, followed by place of work, or school (Fig.7). Over half the sample (56.2\%) used the pier as their primary commuter access point, while the remainder used a combination of road mass transit and motorcycle taxi. This reflects the fact that road, rail mass transit are still not well-linked with the waterborne transport. Thus, many lower-income boat users are forced to walk considerable distances, either from home or a distant bus stop. Motorcycle taxis are not affordable on a daily basis for the lower-income commuter.

BMR urgently needs to provide more affordable feeder system and variety options to the waterborne commuters for daily travel to work and school, especially for those with limited means. Also integration waterborne transport into on-land development plan.

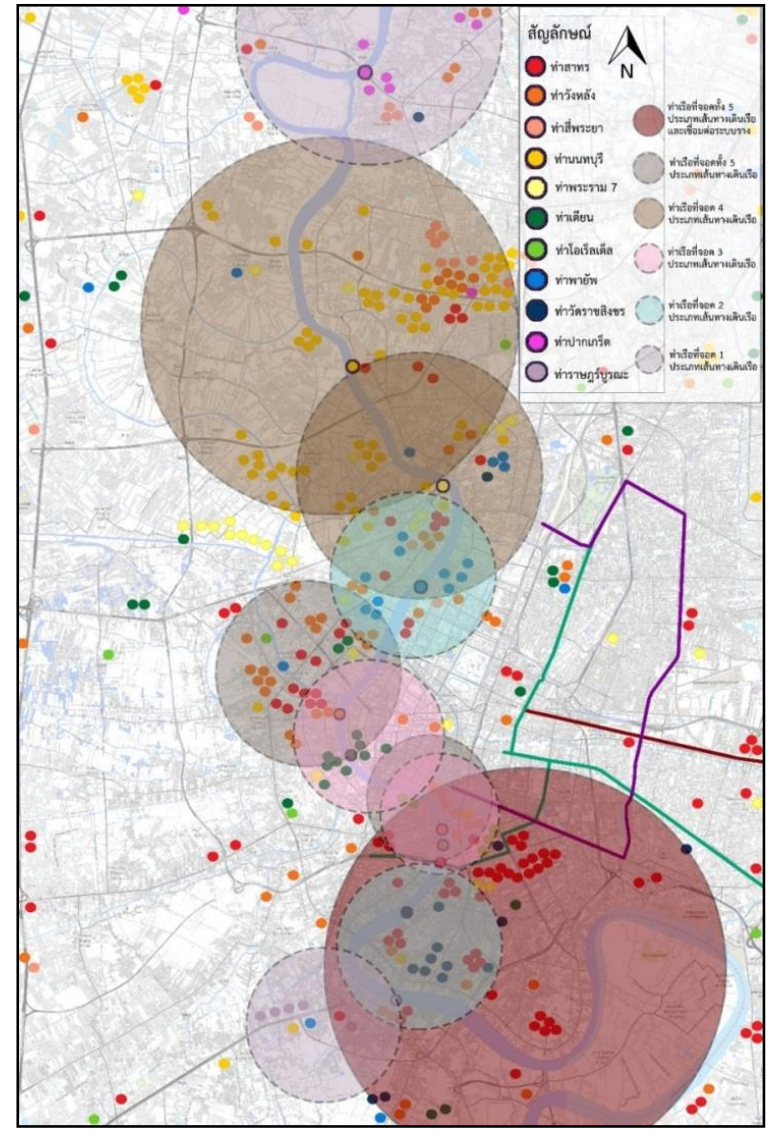

Fig. 6 A Distribution Residents of Waterborne User

(Source: authors) 


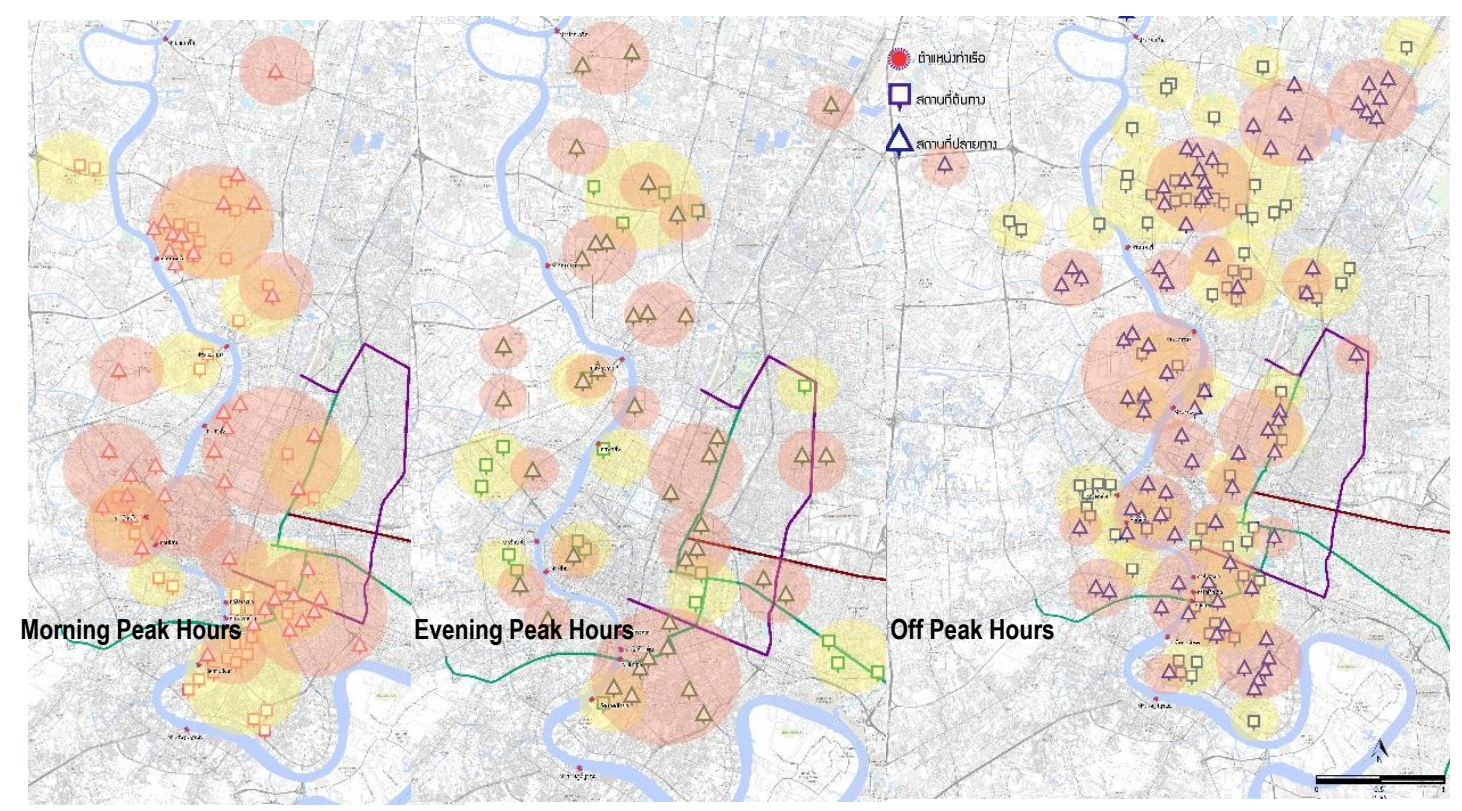

Fig.76 A comparison of travel behavior during different time (Source: authors)

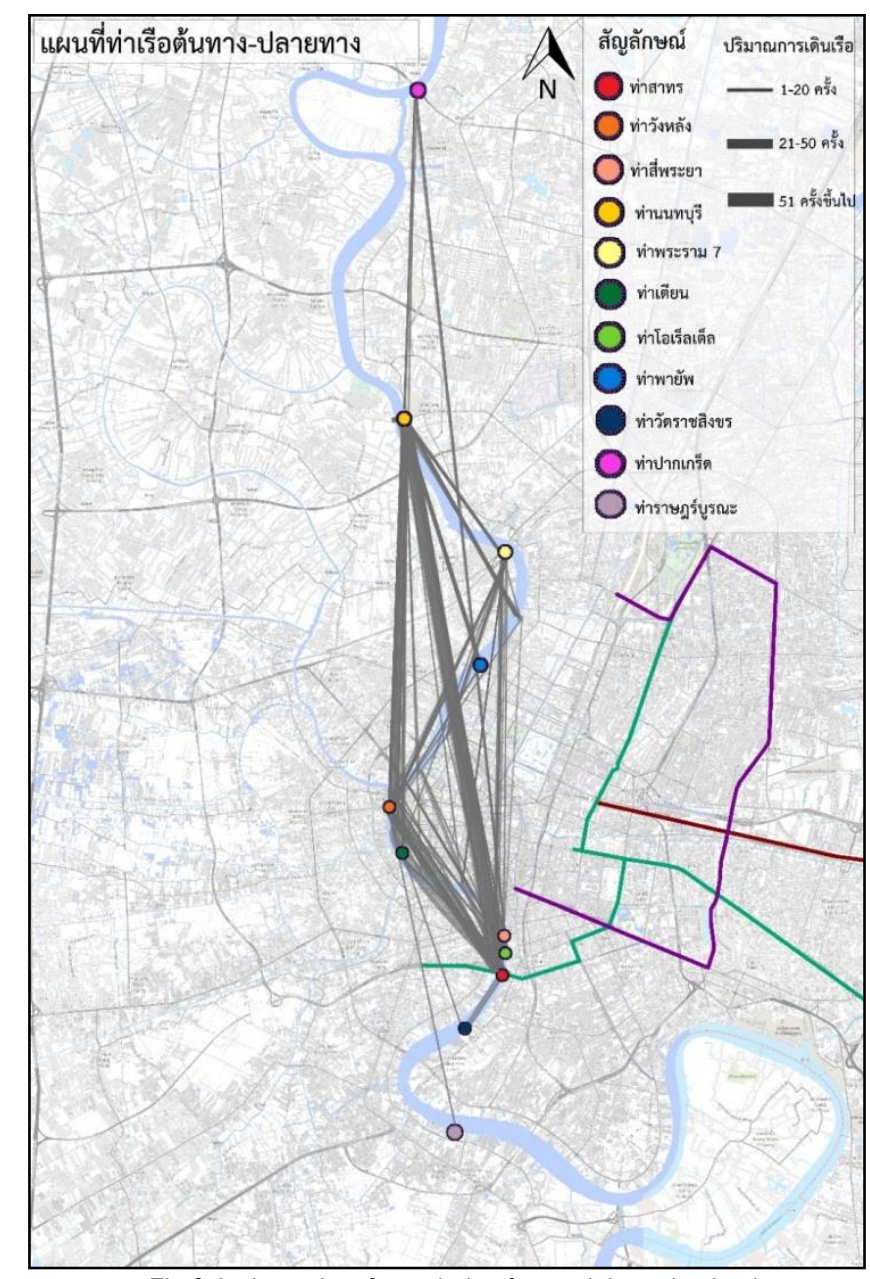

Fig.8 An intensity of travel trips from origin to destination (Source: authors) 
Yupho, S., et.al. / $5^{\text {th }}$ AicQoL2017Bangkok, 25-27 February 2017 / E-BPJ, 2(5), March 2017 (Pp.403-413)

\section{References}

Ashir Lanree, (n.p). The Relationship between Land Use and Transportation, Retrieved November 12, 2016. from https://www.academia.edu/9241489

Bangkok Mass Transit System Public Company Limited. (2011). Retrieved December 10, 2016. from http://www.BTS.co.th/customer/th/images/Master_RouteMap.jpg

Jean-Paul Rodrigue, (2016). Transportation, Activity Systems and Land Use, Retrieved November 16, 2016. From https://people.hofstra.edu/geotrans/eng/ch6en/conc6en/activityuse.html

Land Transport Authority.(2016).Passenger Transport Mode Shares in World Cities, November, $2011 . \quad$ Retrieved December 9, 2016. From https://www.Ita.gov.sg/ltaacademy/doc/J11Nov-p60PassengerTransportModeShares.pdf

Master plan town of Mouth Air, (2003). Land Use and Zoning, Retrieved November 12, 2016. from http://www.mountairymd.org/download/Master-Plan/03MPChap4.pdf

Paul Mitchell Hess, Anne Vernez Moudon, and Miles G. Logsdon,(2544). Measuring Land Use Patterns for transportation Research, Retrieved November $15,2016$. from https://faculty.washington.edu/moudon/writing\% 20docs/measure_landuse.pdf

Tienwanan Jomsueb (2016), Land Use Pattern of Boaryard Areas Along Chao Phraya River (Master's Thesis). Chulalongkorn University, Bangkok, Thailand 